\title{
Connotation of Innovation Education at College and Reflection on Cultivating Innovative Talents
}

\author{
Zhao Shengbin \\ School of Information \& Control engineering \\ Shenyang Jianzhu University \\ Shenyang, China
}

\author{
Feng Jiyuan \\ School of Information \& Control engineering \\ Shenyang Jianzhu University \\ Shenyang, China
}

\begin{abstract}
Innovation is the soul of a nation's progress and development, it is a new era, the important requirement of social development in our country, a country can have a large number of innovative talents with innovative ability directly determines the strength of its comprehensive strength. Whether in any field of any industry, the importance of the cultivation of innovation ability is beyond doubt. Under the background of quality education, the core of education reform is to carry out the strategic plan of building an innovative country. While the university is the important stage that students receive higher education, they can have more time and more chances to contact. Through the understanding of knowledge and their own experimental inquiry to explore the idea and even overthrow the old theory, so that the purpose of innovation education, so that the education sector and even say about the future development of our country's historical mission. This paper from the aspects of the connotation and structure of the innovation education begin to study, currently in China's colleges and universities on innovative personnel training of the existing drawbacks and item by item analysis and put forward feasible solving measures are discussed.
\end{abstract} talents

Keywords-College, education, innovation, innovative

\section{INTRODUCTION}

In 1982, at the Chinese Communist Party's Twelfth Congress, Deng Xiaoping proposed to build socialism with Chinese characteristics, so how to build a "characteristic" of socialism? Of course, innovation, innovation is the source of all development, but also an important force to improve the international competitiveness. Education as an important means to improve the ability of national innovation, plays an important role in a country. But in twenty-first Century, the college students have appeared a phenomenon of mass production, there is no lack of a variety of high knowledge reserves of talent, but few people with innovative ability. University is the key to cultivate students' innovation ability, and cultivate the innovative spirit and innovative ability of higher talent is the specific requirements of College education. How to stimulate students' creative thinking, develop students' innovative ability and practical ability is an important issue of the major colleges and universities as well as the education sector should increase research efforts.
Therefore, we must strengthen the quality education, stimulate students' divergent thinking, and encourage innovation to improve the quality and ability of students.

\section{CONNOTATION AND CONSTITUTION OF INNOVATION EDUCATION AT COLLEGES}

\section{A. Connotation of Innovation Education}

Innovative education is a new education idea which is proposed under the new era. It has abandoned the absolute authority of education, and it is the essential requirement of quality education. The most important of the innovation education is not to say what the final result, the key is the process of education, innovation should be the essence of the whole process of education, and to develop a new generation of innovative talent is the ultimate goal and pursuit of innovative education.

\section{B. Constitution of Innovation Education}

The two important components of innovation education, which is the innovation spirit and innovation ability, is also the two major aspects of the university should focus on cultivating students' ability. Innovation spirit is the premise of innovation activities, is the soul of innovation, no innovation consciousness, innovation spirit, why to talk about innovation? Innovative spirit is a kind of spirit, which is a challenge to the traditional theory, the traditional knowledge, and the spirit of the problem. In life, behave is you must present a state, however, in the pursuit of knowledge, we do not need to, we need is the strong desire to create the spirit, for the spirit of innovation. Of all the unknown can keep a heart of curiosity, of things to ascertain the origin of persistent, at the same time, keep a kind of passion, the newly discovered new pursuit of passion, this is the spirit of innovation is the connotation of the innovation.

Innovation is our thinking during innovative activity and a manifestation of the comprehensive skills, your insight and observation, logical thinking, hands-on experience and language skills, etc., all belong to the category of innovation performance capabilities. With the need for innovation is not only intellectual factors, its value, purpose and confidence and other factors are inseparable relationship, it is more important is their ability to practice in the ideological foundation of the spirit of innovation, the treasures of the mind with innovative ideas current technology, while producing 
socially valuable achievements in the transformation process that is reflected in innovative ability. In general, innovative spirit and ability are interdependent, if there is no practical ability to innovate, and ultimately it can only make innovation become empty talk, can never be achieved.

\section{PRoblems For Colleges to Cultivate INNOVATIVE TALENTS}

Under the influence of the reform and opening up, under the demand of social development of education, more and more colleges and universities began to pay attention to the cultivation of innovative consciousness, the education center gradually shifted to the cultivation of innovative talents. However, the results of the reform of education are not obvious, which still exist many problems. The factors that restrict its development are various and are relatively complex, we will analyze from the following four aspects.

\section{A. Influence of Basic Education Mode, Week Innovation Consciousness}

Because of the influence of historical factors, the traditional education mode and concept are deeply rooted in people's hearts. School has always used the same teaching mode, only pay attention to the students' knowledge, and at the same time, the one-sided pursuit of enrollment rate, so that students in their own state of the best age cannot get the proper education, cannot get the best development. The teacher only to impose their own consciousness on the students, forcing them to do according to their own requirements, there is no active consciousness, not to talk about innovation. In addition, the influence of the exam oriented education is an important factor to hinder the development of the school or society, only a paper on a paper to the students to make a direct impact on the future, which is forcing the school to improve students' culture class scores, in order to improve the rate of rise, so as to be only for the examination of the test part, and neglect the cultivation of students' innovative consciousness and innovative ability.

With the development of the times, the traditional education mode is not suitable for the development of modern education, but the traditional theory of knowledge may not be adapted to the development of modern society. So we have to be in a critical eye to learn, to see anything, dare to challenge the creativity of the first step, is also the innovation consciousness is the most important embodiment of, however, under the traditional concept of education, students and teaching didn't have a chance more, no guts to challenge. This has seriously hindered the development of innovative.

\section{B. Backward Course Contents, Unreasonable Course Setting}

Creative Education on the "new" knowledge content requires an update to constantly update knowledge of the system, we live in the information age, all the time there will be a lot of new content generation, once the new theory of knowledge overthrow content behind after, we must immediately update our knowledge systems and scientific finishing, forming an innovative curriculum.
However, most colleges and universities in this regard is currently not perfect, from the knowledge structure is unreasonable, caliber curriculum is too narrow, students do not have a wide range of choices. Between subjects and disciplines, split between professional and professional too small, only focus on their professional education does not reflect the overall quality of development. The most important set of teaching contents and curriculum have been out of touch with the times, we have been unable to meet the development needs of the community now. Old-fashioned teaching content, old curriculum and irrational structure, there is no injection of fresh blood How to talk about innovation?

Innovative education pays great attention to a new, first of all, teaching method is to be new. In the teaching method, the teacher is more only for the students to carry out the knowledge, the emphasis on the inheritance of the old knowledge as well as the master of examination skills, a serious distortion of the nature of education. Eventually led to the consistency of the students thinking, lose their personality, no personality is no innovation. Pay attention to the classroom to transfer, should pay more attention to the students' thinking and the ability to practice. But now the university school teacher lecture is inflexible and single, unable to stimulate students' interest in learning, not a good atmosphere for learning how to innovate?

\section{Week Practical Link}

The practice is the only standard to test the truth. The practice teaching is the supplement and strengthening of the theory teaching. It is the basis for the students to enter the society and take over the job. However, at present, most of the colleges and universities often lack of practical teaching because of the lack of funds, they are often just the practice design in graduation design or practice, the purpose is to let the students on the content of the course, not to say that the students themselves to think, to design this experiment, and the requirements of innovative education completely. For students, not enough to get the opportunity to practice. For innovative teaching, theoretical practice is indispensable, but the neglect of practical teaching in Colleges and universities has hindered the development and progress of innovative education from the objective, and the innovation ability of the students is weak, which cannot meet the needs of the society.

\section{EFFeCtive Ways For Colleges to Cultivate INNOVATIVE TALENTS}

\section{A. Innovation of Education Concepts}

To cultivate innovative talents, the premise is to establish the concept of innovation education, the social information is large, the information transmission is very fast, and the speed of updating knowledge is accelerating. University is the important stage of students to accept higher education, but also the most prone to dispute, the knowledge of students in the future work need to change, so, it is stressed that teachers should teach students to learn independently, to explore, to learn how to innovate. Innovative education advocates the need to cultivate the students' innovation ability, first of all, we should set up 
the innovation consciousness and realize the importance of innovation. To establish a democratic, open, change education ideas, establish a correct view of knowledge and talent. First of all, the renewal of ideas, training innovative talents to enhance national innovation, and the rise and fall of the nation, in order to provide a strong guarantee for the reform of education. With the concept of innovation will stimulate the desire of innovation, decision makers should guide the right direction for the innovation of education, to ensure the healthy development of education system.

\section{B. Innovation of Training Mode}

The innovation of the training mode is to use the talent training mode, so that the problem can be positive thinking, serious discussion. Change the traditional teaching methods to improve students' learning interest, and to release them from the boring classroom. With the reform of the education system, the change of the focus of education, the traditional teaching methods cannot meet the needs of the current stage of classroom education. Should mobilize the enthusiasm of the students, the teacher will give the basic knowledge to the students, should pay attention to guide, so that students themselves divergent thinking, cooperative inquiry. To encourage the same problem to analyze from different directions, to cultivate students' ability to see the problem in many angles.

In addition, we should teach students a selfexploration, innovation awareness, teacher, and are not necessarily on the textbook, and their own daring to question the pursuit of seeking truth from facts, encounter problems, ask questions, common solutions. Parents also should change the old-fashioned idea, abandon score is to assess the quality standards of learning, students can decide according to their own interests to explore which aspects of the content. Teachers in the teaching process should focus on the quality rather than the quantity of lectures, not taskbased teaching, to ensure that students are able to fully grasp the contents of grant. Teaching should use a lot of humor in the language, the more abstract concepts vivid explanation out, so boring classroom becomes more fun.

\section{Innovation of Practical Teaching}

According to the traditional teaching methods, assess whether students master the knowledge of the true standard is to see whether students can answer in the papers, but, according to the requirements of innovative education, students' theoretical knowledge in the church, to give them hands-on opportunities for the future into the community, into the social experience of job creation. After only through practice, with theoretical knowledge to strengthen memory and fully understood in order to be regarded as the real master, and then if we can, through their own understanding and study of the overthrow of the old theory, or to create their own new theory, this is an Innovation. Therefore, in order to achieve this goal, first of all, schools should provide students with a platform to be able to fully carry out the practice, and then organize a variety of practical activities to encourage students to actively participate, you can set a variety of incentives or concessions to mobilize the enthusiasm of students. Some issues have a lot of creative design, to encourage students to leave the campus into the community to investigate, to study, through their side of the case to get ideological inspiration. In addition, the school with other schools and even some social institutions to cooperate, while students also strengthen innovation ability of students' social skills, so that students so that students see the world broader, and skills have been improved in all aspects.

\section{CONCLUSION}

In today's society, knowledge reserves of college students are everywhere, but what we need and the country needs is characteristic persons: you have to have the innovation ability, you have skills in order to gain a firm foothold in the competition. Students are the future of the motherland, colleges and universities are training students' innovation ability is an important node, must focus on. However, innovation cannot be overanxious for quick results, we must explore in continuous learning slowly realize, still need the education sector to explore slowly.

\section{REFERENCES}

[1] Zeng Zhenping, Shen Zhenfeng. On Cultivating Innovating Teaching Methods and Innovating Talents at Colleges [J]. Journal of Huazhong Agricultural University, 2009 (05).

[2] He Yunlong, Cui Yuxiang. Organizational Teaching Centered at Cultivating Innovative Talents [J]. Research into Higher Education in China, 2005(9).

[3] Li Shihai, Gao Zhaohong, Zhang Xiaoyi. Exploration into Innovation Education [M]. Beijing: Social Science Literature Press, 2005.

[4] Zhao Jiayi. Outline of Innovative Education [M]. Chengdu: Sichuan Education Press, 2005.

[5] Wu Baogui. In-depth Reflection on the Mode of Cultivating New Innovative Talents in Colleges [J]. Journal of Harbin Institute of Technology (social science edition), 2007 (3) : 115-119.

[6] Qiu Jingli. Exploration of Cultivating New Innovative Talents at Colleges [J]. Economists, 2007, (4) : 109-110.

[7] Liu Tian'e, Tan Min. On Establishing Mode of Cultivating Innovative Talents at Colleges [J]. Journal of Wuhan Institute of Metallurgy Administrators, 2008(3).

[8] Chen Yilin. Innovative talent cultivation in Colleges and universities in the perspective of the development of colleges and Universities [J]. Private Higher Education, 2007(3).

[9] Liu Haibo, Wang Fengling. On the reasonable scale of higher education in China from international comparison $[\mathrm{J}]$. Prospect of Global Education, 2006, (11).

[10] Guo Guangsheng. Thinking on cultivating innovative talents in high level research universities [J]. Higher Education in China, 2006, (10).

[11] Zhang Guichun, Zhang Ping. How to cultivate innovative capacity in quality education of college students $[\mathrm{J}]$. Science Education,2005,(06) 